\title{
Prevalence and Characteristics of Basal Core Promoter Mutations in Iran and its Correlation with Acute and Chronic Hepatitis B Infection
}

\author{
Sadegh Nasrollaheian ${ }^{1}$, Gholamreza Farshidfar ${ }^{2}$, Ali Kargar Kheirabad ${ }^{3}$, Hamed Gouklani ${ }^{4}$
}

${ }^{1}$ M.Sc., Pharmaceutical Sciences Branch, Islamic Azad University, Tehran, Iran

${ }^{2}$ MD., Department of Biochemistry, School of Medicine, Hormozgan University of Medical Sciences, Iran

${ }^{3}$ Ph.D., Department of Virology, School of Public Health, Tehran University of Medical Sciences, Tehran, Iran

${ }^{4}$ Ph.D., Molecular Medicine Research Center, Hormozgan Health Institute, Hormozgan University of Medical Sciences, Bandar Abbas, Iran

\section{Type of article: Original}

\begin{abstract}
Introduction: Manifestations of HBV infection differ in chronic and acute phases. Therefore, identifying the determinants such as mutations has a vital role in the treatment of the disease. A dual transversion in the basal core promoter $(\mathrm{BCP})$ region is common among HBV patients. Thus, the present study was conducted with the objective of determining the prevalence of basal core promoter (BCP) mutations and its correlation with the outcome of HBV infection.

Method: In this cross-sectional study, samples were obtained from 182 Iranian HBsAg positive patients who were admitted to the Bandar Abbas Blood Transfusion Organization in 2012 and 2013. They were screened by ELISA test using commercial kits to detect serological marker anti-HBc IgM for distinct chronic hepatitis from acute infection. Thereafter, the extracted DNA was used for determination of the BCP mutations by PCR-RFLP technique. Data analyses were performed with SPSS 12 by Mann-Whitney U test, Fisher's exact probability test, and t-test.

Results: BCP mutations were observed in 15 samples $(8.24 \%)$ of the study population, and serological tests determined that, among the BCP mutants, one sample (6.67\%) was $\mathrm{HBeAg}$ positive, 14 samples $(93.33 \%)$ were $\mathrm{HBeAg}$ negative, and four samples $(2.2 \%)$ were positive for anti-HBc IgM test. Data analysis indicated a statistically significant association between BCP mutations and acute hepatitis $(p=0.002)$. However, no relationship was detected between the prevalences of the BCP mutations and gender of subjects $(\mathrm{p}>0.567)$.

Conclusions: The prevalence of BCP variants was low in the south of Iran, and this mutation can lead to acute phase of viral hepatitis.

Keywords: Acute hepatitis B, Chronic hepatitis B, Basal core promoter, Epidemiology
\end{abstract}

\section{Introduction}

Hepatitis B infection is a universal health problem, resulting in nearly 350 million chronically infected carriers worldwide (1). The range of the manifestations of HBV infection differs in chronic and acute phases. In the chronic phase, symptoms vary from an asymptomatic state to cirrhosis and hepatocellular carcinoma. However, manifestations of acute phase range from icteric to anicteric hepatitis and in some cases fulminant hepatitis (2). Determination of this issue plays an important role in the treatment and management procedure of the disease. Thus, it is important to identify $\mathrm{HBV}$-infected patients who are at a higher risk for disease progression to the chronic phase (3). Previous observations illustrated up to $90 \%$ of infants and $5 \%-10 \%$ of adults with acute HBV infection progress to chronic hepatitis B (4). Although lots of determinants can identify the progression and outcome of HBV infection, many surveys have demonstrated that development of infection is mainly influenced by the viral factors, including genomic variations (5). The mutations are usually observed due to the spontaneous error rate of viral reverse

\section{Corresponding author:}

Dr. Hamed Gouklani, Molecular Medicine Research Center, Hormozgan University of Medical Sciences, Bandar Abbas, Iran. Tel: +989365966501, Email: gouklanih@gmail.com

Received: April 23, 2016, Accepted: August 07, 2016, Published: December 2016

iThenticate screening: August 03, 2016, English editing: October 09, 2016, Quality control: November 17, 2016

(C) 2016 The Authors. This is an open access article under the terms of the Creative Commons Attribution-NonCommercialNoDerivs License, which permits use and distribution in any medium, provided the original work is properly cited, the use is non-commercial and no modifications or adaptations are made. 
transcriptase. Based on the literature, among these mutants, variations in the basal core promoter (BCP) region of the genome may be related to the outcomes of HBV infection $(6,7)$. In fact, a dual transversion in the basal core promoter (BCP) region (nt 1742-1849) of the HBV genome, involving an A to T substitution at nucleotide 1762 (A1762T) and a G to A mutation at nucleotide 1764 (G1764A), is often observed in chronic hepatitis (8). However, controversy exists regarding the presence of the mutations during the acute phase. Although the majority of investigations have indicated the association between basal core promoter mutations and chronic phase of hepatitis $\mathrm{B}$ infection, others have described that these alternations can be found in acute hepatitis (9). The importance of determining the association between BCP mutations and HBV outcome is mainly considerable in weak populations such as old age (10), children (11), and infants (12) and also immunocompromised patients (13). In accordance with the literature, the highest transmission risk of these variants is in blood transfusion centers. On the other hand, there is a lack of documentation regarding the prevalence and characteristics of BCP mutations in Iran, especially in Bandar Abbas City. In addition, Bandar Abbas is one the main communication ports of Iran with the Persian Gulf countries. Therefore, in the present research, we assessed the prevalence and characteristics of BCP mutations in Bandar Abbas, Iran, and its correlation with the outcome of HBV infection.

\section{Material and Methods}

\subsection{Research design}

This single-center cross-sectional study was carried out in the Bandar Abbas Blood Transfusion Organization in 2012 and 2013. Enrolled patients provided written informed consent, and those who did not consent to participate were ruled out.

\subsection{Sampling}

A total of $182 \mathrm{HBsAg}$ positive patients admitted to the Bandar Abbas Blood Transfusion Organization in 2012 and 2013 were recruited in the study by census sampling method. Serum samples were obtained from the subjects, including 144 (79.12\%) males and 38 (20.88\%) females.

\subsection{Data collection}

All patients were examined for anti-HIV (human immunodeficiency virus), anti-HCV (hepatitis C virus), and antiHDV (hepatitis D virus) antibodies (Ab), and then the positive samples were excluded from the project. In addition, based on patient records, those who received antiviral treatment and those with recurrent hepatitis B after liver transplantation were ruled out. These patients were excluded due to the impact of treatment on serum HBV DNA levels and the possibility that antiviral therapy might have an effect on core promoter variants. The serum samples were evaluated by ELISA test using commercial kits (DIAPRO, Italy) to detect serological marker anti-HBc IgM according to the manufacturer's instructions. An anti-HBc IgM test was used to determine chronic hepatitis from acute infection. Thereafter, DNA was extracted from sera with the Roche High Pure Viral Nucleic Acid kit (Roche Molecular Biochemicals, Germany) by proteinase K and sodium dodecyl sulphate (SDS) treatment followed by phenol/chloroform/isoamylic alcohol (25/24/1) reagent and ethanol precipitation depending on the manufacturer's protocol. Thereafter, the extracted DNA was used for determination of the basal core promoter mutations by PCRRFLP technique. Indeed, the core promoter region was amplified via PCR and then excised by specific restriction enzymes. To do the procedure, two HBV primers (Core1 and Core2) were used in the first PCR amplification. An aliquot of reaction product was then further amplified in the second reaction with primers, Core1 and Core3. The primer sequences were Core1, 5'-GCATGGAGACCACCGTGAAC-3' (sense, nt 1606-1625); Core2, 5'GGAAAGAAGTCAGAAGGCAA-3' (antisense, nt 1974-1955); Core3, 5'- GGCAAAAAAGAGAGTAACTC-3' (antisense, nt 1959-1940). A $5 \mu \mathrm{L}$ of the resuspended DNA was added to an amplification mixture containing $2.5 \mu \mathrm{L}$ of $10 \times$ Taq polymerase buffer, $0.5 \mu \mathrm{L}$ of $25 \mathrm{mmol} / \mathrm{L}$ deoxyribonucleotide triphosphates, $0.75 \mu \mathrm{L} \mathrm{Mgcl} 2,0.5 \mu \mathrm{L}$ of Taq polymerase (Promega, Beijing, China), and one $\mu \mathrm{moL}$ each of primers Core 1 and Core 2 (total volume of 25 $\mu \mathrm{L})$. Then, for the second cycle, a $1 \mu \mathrm{L}$ of the first-round PCR products was added to an amplification mixture containing $5 \mu \mathrm{L}$ of $10 \times$ Taq polymerase buffer, one $\mu \mathrm{L}$ of $25 \mathrm{mmol} / \mathrm{L}$ deoxyribonucleotide triphosphates, $1.5 \mu \mathrm{L}$ $\mathrm{Mgcl}_{2}, 1 \mu \mathrm{L}$ of Taq polymerase (Promega, Beijing, China), and $2 \mu \mathrm{moL}$ each of primers Core1 and Core3 (total volume of $25 \mu \mathrm{L}$ ). The PCR profile was similar in both amplification cycles: an initial 5 min denaturation at $94^{\circ} \mathrm{C}$, followed by 35 cycles of amplification including denaturation for $45 \mathrm{~s}$ at $94^{\circ} \mathrm{C}$, annealing for $45 \mathrm{~s}$ at $58^{\circ} \mathrm{C}$, and extension for $45 \mathrm{~s}$ at $72^{\circ} \mathrm{C}$. Strand synthesis was completed at $72^{\circ} \mathrm{C}$ for $1 \mathrm{~min}$. Finally, the PCR products were incubated with restriction enzyme Sau3AI that recognize 5'-GATC-3' sequence and cut the amplified segment into two fragments of $157 \mathrm{bp}$ and $197 \mathrm{bp}$ in length. However, in absence of PC mutation, the production was a fragment of $354 \mathrm{bp}$ in length. The products were visualized by $3 \%$ agarose electrophoresis and ethidium bromide staining. 
The PCR products were incubated with restriction enzymes Ava II and MboI (New England Biolabs, Inc., USA) for $16 \mathrm{~h}$ at $37^{\circ} \mathrm{C}$ in a $15 \mu \mathrm{L}$ reaction sample according to the manufacturer's recommendations.

\subsection{Statistical analysis}

Data handling and analyses were performed with SPSS software for Windows, version 12.0, and a $p<0.05$ was considered statistically significant. Proportions of each factor were compared between groups using the MannWhitney U test and the Fisher's exact probability test, and group means were compared using the $t$-test.

\section{Results}

No serum samples were excluded from the study during the research period, and all of the 182 serums were remained in present study. Thirty-eight $(20.88 \%)$ were female and $144(79.12 \%)$ were male. Basal core promoter mutations were observed in 15 samples $(8.24 \%)$ of the study population, which created two fragments of $197 \mathrm{bp}$ and $157 \mathrm{bp}$ in length, which were detectable by electrophoresis (Figure 1). Serological tests determined that, among the basal core promoter mutants, one sample (6.67\%) was HBeAg positive, 14 samples (93.33\%) were HBeAg negative, and four samples $(2.2 \%)$ were positive for anti-HBc IgM test. As illustrated in Table 1, among the anti-HBc IgM positive samples, two samples (50\%) were the BCP mutants. Thus, data analysis indicated a statistically significant association between basal core promoter mutations and acute hepatitis $(p=0.002)$. Eight samples $(53.33 \%)$ of the core promoter mutants were female and the others were male. Further analysis described no relationship between the prevalences of the BCP mutations and gender of subjects $(\mathrm{p}>0.567)$.

Table 1. Analytical analysis of the study variables

\begin{tabular}{|l|l|l|l|l|}
\hline \multicolumn{2}{|l|}{ Variables } & Mutants & Wild types & $p$-value \\
\hline \multirow{2}{*}{ Gender } & Male & $14(7.7 \%)$ & $62(34.1 \%)$ & 0.567 \\
\cline { 2 - 5 } & Female & $19(10.4 \%)$ & $87(47.8 \%)$ & \\
\hline \multirow{2}{*}{ Outcome } & Acute & $2(50 \%)$ & $2(50 \%)$ & 0.002 \\
\cline { 2 - 4 } & Chronic & $13(7.3 \%)$ & $165(92.7 \%)$ & \\
\hline
\end{tabular}

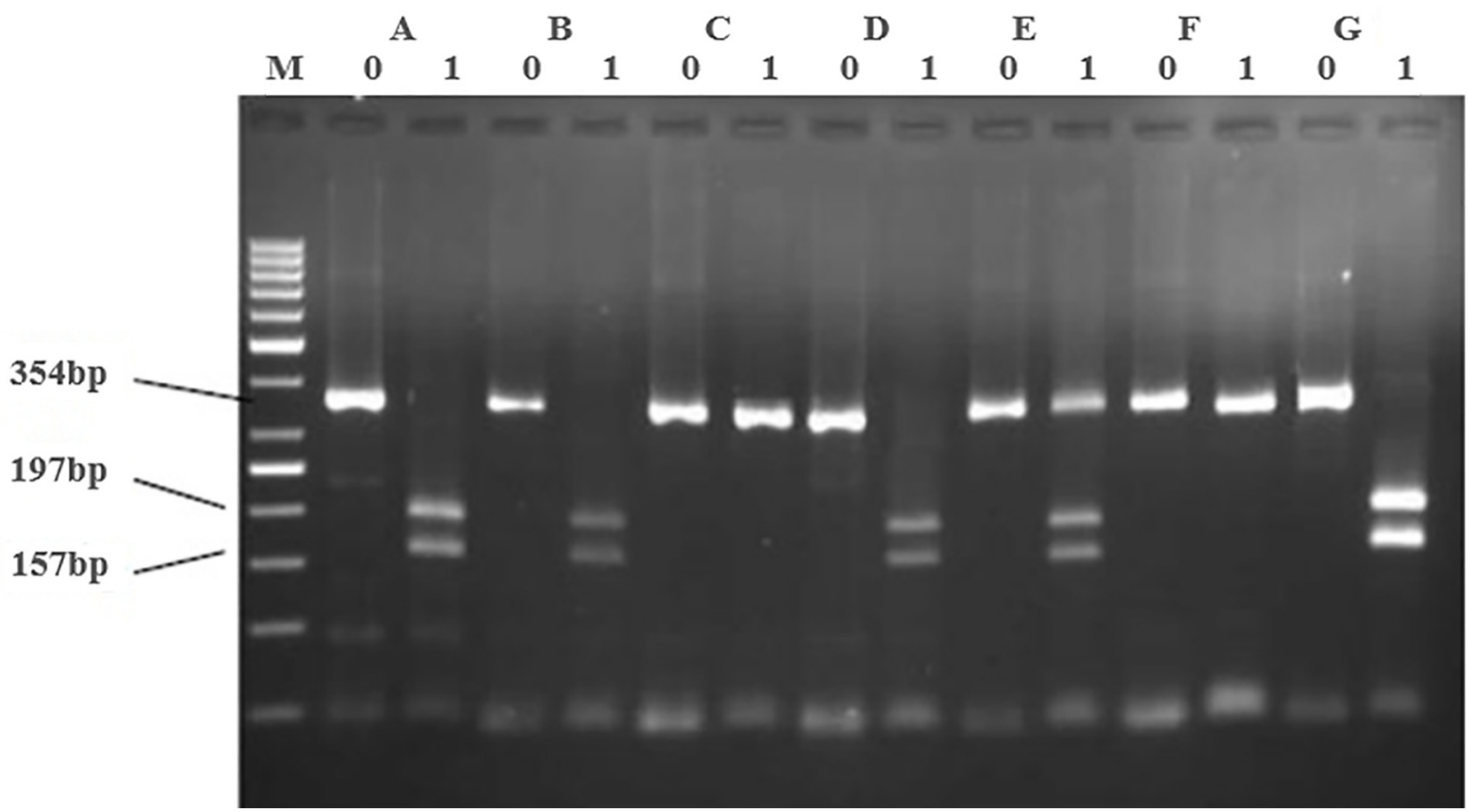

Figure 1. Representative patterns on agarose gel electrophoresis demonstrating the restriction enzyme-based detection of basal core promoter mutants and variants. Each analysis is represented by two lanes: (1) the left without and (2) the right with a restriction enzyme Sau3AI added. C and F show the wild-type (354bp): A, B, D, and G show mutants (157 bp, $197 \mathrm{bp}$ ). E shows a mixture of wild types and mutants. M: Marker $50 \mathrm{bp}$. 


\section{Discussion}

HBeAg is derived from the precore and core gene of Hepatitis B virus, and mutations of which can lead to changes in the sequence, structure, antigenicity, and also the biological functions of $\mathrm{HBeAg}(14)$. In accordance to this literature, we found that the majority of BCP mutants $(93.33 \%)$ were HBeAg negative in the present project. Lots of previous studies reported this seroconversion as the main cause of the association between BCP mutations and disease progression (15). Taking together the lines of evidence, it could be suggested that the prevalence of BCP mutations in each population might serve as a risk calculator and predictor for cirrhosis development in HBV carriers (16). Thus, patients with BCP mutant should consider prevention treatment for cirrhosis. The findings of this work showed that the prevalence of BCP mutations among the HBsAg positive patients in the south of Iran was relatively low (8.24\%). However, Chu et al. ascertained that core promoter variants were found in $44 \%$ of patients with chronic HBV infection in the United States. The authors suggested that the influx of immigrants from East and Southeast Asia in recent years may cause this epidemiology of HBV infection in the United States (17). The considerable differences between these investigations and various populations may be due to several factors, including age, HBV genotype, ethnicity, previous antiviral therapy, and hepatic decompensation. Based on the reported observations, the mutations are more prevalent in genotypes B and C of HBV genotypes, which are the major genotypes in East and Southeast Asia and Australia (18), where more than half of the estimated carriers in the world live (19). These arguments are in agreement with the study of Chu et al. (17). On the other hand, genotype D is the major genotype of HBV in Iran, which has a lesser ability for BCP mutations. Therefore, it is reasonable that the prevalence of the mutation in core region of HBV in Iranian carriers are low $(20,21)$. Clinical manifestations of HBV infection differ from simple mental disorders (22-24) to life-threatening outcomes, depending on features of the infected person and genetic characteristics of the virus $(25,26)$. Several studies in recent years have proposed that HBV carriers with T1762/A1764 basal core promoter mutant are at increased risk for chronic hepatitis and hepatocellular carcinoma (27), while our results indicated a significant association between basal core promoter mutations and acute phase of hepatitis. In fact, this study demonstrated equal amounts of core promoter mutation in both of the acute and chronic phases of hepatitis. This observation is in agreement with the findings of two studies conducted by X Ren et al. and R Gérolami et al. The authors believed that the changes in the basal core promoter region of the hepatitis B virus DNA can increase the risk of acute and even the fulminant hepatitis (28, 29). However, the findings of this investigation should be presented with caution, as the present study was limited in several ways: first, the relatively small size of study population due to limited numbers of the visitors; second, lack of consideration of different HBV genotypes due to their genomic differences; finally, lack of consideration the racial differences and migrants.

\section{Conclusions}

In conclusion, the prevalence of BCP variants was low in the south of Iran, and this mutation can lead to acute and chronic phase of viral hepatitis with the same chance. Therefore, healthcare authorities and blood transfusion centers can perform additional screening tests for BCP mutations, at least for high-risk groups, including old age, children, and immunocompromised patients. In future studies, it is suggested to consider different HBV genotypes and also the racial differences and migrants in larger projects.

\section{Acknowledgments:}

This article is extracted from the author's postgraduate thesis. The authors would like to thank the Student Research Committee of Hormozgan University of Medical Sciences for its help and support.

\section{Conflict of Interest:}

There is no conflict of interest to be declared.

Authors' contributions:

All authors contributed to this project and article equally. All authors read and approved the final manuscript.

\section{References:}

1) Carman WF, Thursz M, Hadziyannis S, McIntyre G, Colman K, Gioustoz A, et al. Hepatitis B e antigen negative chronic active hepatitis: hepatitis B virus core mutations occur predominantly in known antigenic determinants. J Viral Hepatitis. 1995; 2(2): 77-84. doi: 10.1111/j.1365-2893.1995.tb00010.x. PMID: 7493301 . 
2) Huang Y, Deng H, Peng Z, Huang Y, Long Q, Huang A. Mutations of Basal core promoter and precore regions in hepatitis $B$ virus genotypes $B$ and $C$. Hepat Mon. 2014; 15(1): e23034. doi: 10.5812/hepatmon.23034. PMID: 25741368, PMCID: PMC4344649.

3) Liu CJ, Chen BF, Chen PJ, Lai MY, Huang WL, Kao JH, et al. Role of hepatitis B viral load and basal core promoter mutation in hepatocellular carcinoma in hepatitis B carriers. J Infect Dis. 2006; 193(9): 1258-65. doi: 10.1086/502978. PMID: 16586363.

4) Lok AS, McMahon BJ. Chronic hepatitis B. Hepatology. 2007; 45(2): 507-39. doi: 10.1002/hep.21513. PMID: 17256718.

5) Chisari FV, Isogawa M, Wieland SF. Pathogenesis of hepatitis B virus infection. Pathol Biol (Paris). 2010; 58(4): 258-66. doi: 10.1016/j.patbio.2009.11.001. PMID: 20116937, PMCID: PMC2888709.

6) Hunt CM, McGill JM, Allen MI, Condreay LD. Clinical relevance of hepatitis B viral mutations. Hepatology. 2000; 31(5): 1037-44. doi: 10.1053/he.2000.6709. PMID: 10796877.

7) Günther S, Fischer L, Pult I, Sterneck M, Will H. Naturally occurring variants of hepatitis B virus. Adv Virus Res. 1999; 52: 25-137. doi: 10.1016/S0065-3527(08)60298-5. PMID: 10384235.

8) Tong MJ, Blatt LM, Kao JH, Cheng JT, Corey WG. Basal core promoter T1762/A1764 and precore A1896 gene mutations in hepatitis B surface antigen - positive hepatocellular carcinoma: a comparison with chronic carriers. Liver Int. 2007; 27(10): 1356-63. doi: 10.1111/j.1478-3231.2007.01585.x. PMID: 17900245, PMCID: PMC2229667.

9) Xu Z, Ren X, Liu Y, Li X, Bai S, Zhong Y, et al. Association of hepatitis B virus mutations in basal core promoter and precore regions with severity of liver disease: an investigation of 793 Chinese patients with mild and severe chronic hepatitis B and acute-on-chronic liver failure. J Gastroenterol. 2011; 46(3): 391400. doi: 10.1007/s00535-010-0315-4. PMID: 20848146.

10) Qu L, Kuai X, Liu T, Chen T, Ni Z, Shen X. Pre-S deletion and complex mutations of hepatitis B virus related to young age hepatocellular carcinoma in Qidong, China. PLoS One. 2013; 8(3): e59583. doi: 10.1371/journal.pone.0059583. PMID: 23555717, PMCID: PMC3610697.

11) Hamadiyan H, Pour Ashouri F, Rasekhi S. Growth of Head Circumference, Weight and Height from Birth to 18 Months in the South of Iran. International Electronic Journal of Medicine. 2015; 4(1): 1-5.

12) Parvar N, Moayedi AR, Rasekhi S. An infant Presenting with Cerebrovascular Accident was Diagnosed as a Sickle Cell Disease Patient: a Case Report. International Electronic Journal of Medicine. 2016; 5(1): 23 4.

13) Igaki N, Nakaji M, Moriguchi R, Akiyama H, Tamada F, Oimomi M, et al. An outbreak of fulminant hepatitis B in immunocompromised hemodialysis patients. J Gastroenterol. 2003; 38(10): 968-76. doi: 10.1007/s00535-003-1180-1. PMID: 14614604.

14) Ito K, Kim KH, Lok AS, Tong S. Characterization of genotype-specific carboxyl-terminal cleavage sites of hepatitis B virus e antigen precursor and identification of furin as the candidate enzyme. J Virol. 2009; 83(8): 3507-17. doi: 10.1128/JVI.02348-08. PMID: 19193799, PMCID: PMC2663268.

15) Tseng TC, Liu CJ, Yang HC, Chen CL, Yang WT, Tsai CS, et al. Higher proportion of viral basal core promoter mutant increases the risk of liver cirrhosis in hepatitis B carriers. Gut. 2015; 64(2): 292-302. doi: 10.1136/gutjnl-2014-306977. PMID: 24763132.

16) Lee MH, Yang HI, Liu J, Batrla - Utermann R, Jen CL, Iloeje UH, et al. Prediction models of long - term Cirrhosis and hepatocellular carcinoma risk in chronic hepatitis B patients: Risk scores integrating host and virus profiles. Hepatology. 2013; 58(2): 546-54. doi: 10.1002/hep.26385. PMID: 23504622.

17) Chu CJ, Keeffe EB, Han SH, Perrillo RP, Min AD, Soldevila-Pico C, et al. Prevalence of HBV precore/core promoter variants in the United States. Hepatology. 2003; 38(3): 619-28. doi: 10.1053/jhep.2003.50352. PMID: 12939588.

18) Pivert A, Servant-Delmas A, Lunel-Fabiani F, Le Guillou-Guillemette H, Laperche S, Ducancelle A. Correlation between the promoter basal core and precore mutations and HBsAg quantification in French blood donors infected with hepatitis B virus. J Med Virol. 2015; 87(3): 529-35. doi: 10.1002/jmv.24064. PMID: 25170961.

19) Shiina S, Fujino H, Uta Y, Tagawa K, Unuma T, Yoneyama M, et al. Relationship of HBsAg subtypes with $\mathrm{HBeAg} / \mathrm{anti}-\mathrm{HBe}$ status and chronic liver disease. Part I: Analysis of $1744 \mathrm{HBsAg}$ carriers. Am J Gastroenterol. 1991; 86(7): 866-71. PMID: 2058629.

20) Taghavi SA, Tabibi M, Eshraghian A, Keyvani H, Eshraghian H. Prevalence and clinical significance of hepatitis B Basal core promoter and precore gene mutations in southern Iranian patients. Hepat Mon. 2010; 10(4): 294-7. PMID: 22312396, PMCID: PMC3271323. 
21) Amini - Bavil - Olyaee S, Sarrami - Forooshani R, Mahboudi F, Sabahi F, Adeli A, Noorinayer B, et al. Genotype characterization and phylogenetic analysis of hepatitis B virus isolates from Iranian patients. J Med Virol. 2005; 75(2): 227-34. doi: 10.1002/jmv.20261. PMID: 15602742.

22) Pour Ashouri F, Rasekhi S. A Review on Medical Students Mental Health Problems and Proposed Solutions. International Electronic Journal of Medicine. 2015; 4(1): 23-31.

23) Hesam AA, Taghipour L, Rasekhi S, Fallahi S, Hesam Z. Investigating the Multiple Aspects of Mental Health in Infertile Women. Int J Ment Health Addict. 2016; 1-5. doi: 10.1007/s1 1469-016-9675-1.

24) Pour Ashouri F, Rasekhi S. Correlation between Religious Beliefs with Mental Health and Academic Performance in Medical Students. International Electronic Journal of Medicine. 2016; 5(1): 1-6.

25) Guillevin L, Mahr A, Callard P, Godmer P, Pagnoux C, Leray E, et al. Hepatitis B virus-associated polyarteritis nodosa: clinical characteristics, outcome, and impact of treatment in 115 patients. Medicine (Baltimore). 2005; 84(5): 313-22. doi: 10.1097/01.md.0000180792.80212.5e. PMID: 16148731.

26) Fard SA, Rasekhi S, Ashoorian MJ, Parvizpanah A. Knowledge of dentists of Bandar Abbas toward anaphylactic shock. Int J PharmTech Res. 2016; 9(4): 299-302.

27) Kao JH, Chen PJ, Lai MY, Chen DS. Basal core promoter mutations of hepatitis B virus increase the risk of hepatocellular carcinoma in hepatitis B carriers. Gastroenterology. 2003; 124(2): 327-34. doi: 10.1053/gast.2003.50053. PMID: 12557138.

28) Ren X, Xu Z, Liu Y, Li X, Bai S, Ding N, et al. Hepatitis B virus genotype and basal core promoter/precore mutations are associated with hepatitis B - related acute - on - chronic liver failure without pre - existing liver cirrhosis. J Viral Hepat. 2010; 17(12): 887-95. doi: 10.1111/j.1365-2893.2009.01254.x. PMID: 20070500, PMCID: PMC2998700.

29) Gérolami R, Henry M, Borentain P, Colson P, Botta D, Tamalet C. Fulminant hepatitis B associated with a specific insertion in the basal core promoter region of hepatitis B virus DNA after immunosuppressive treatment. Clin Infect Dis. 2005; 40(4): e24-e7. doi: 10.1086/427146. PMID: 15712066. 